\title{
Kinetic Modelling and Half-Life Study on Enhanced Soil Bioremediation of Bonny Light Crude Oil Amended with Crop and Animal-Derived Organic Wastes
}

\author{
Samuel E Agarry*, Mujidat O Aremu and Oluwafunmilayo A Aworanti
}

Department of Chemical Engineering, Ladoke Akintola University of Technology, P.M.B. 4000, Ogbomoso-Ilorin Road, Ogbomoso, Oyo State, 260001, Nigeria

\begin{abstract}
In this study, the potential effects of crop and animal-derived organic wastes as nutrient supplements to biostimulate autochthonous microflora for hydrocarbon biodegradation were investigated. Microcosms containing soil were spiked with weathered Bonny light crude oil (WBLCO) $(10 \% \mathrm{w} / \mathrm{w})$ and amended with various amounts of groundnut shell, beans shell, melon shell, cassava peels, cow dung and pig dung alone or in combinations. The rates of biodegradation of the crude oil were studied for a remediation period of 42 days under laboratory conditions. The results showed that there was a positive relationship between the rate of petroleum hydrocarbons biodegradation and presence of the crop and animal-derived organic wastes alone or in combination in soil microcosms contaminated with crude oil. The WBLCO biodegradation data fitted well to the first-order kinetic model. The model revealed that WBLCO contaminated-soil microcosms amended with crop and animal-derived organic wastes had higher biodegradation rate constants $(k)$ as well as lower half-life times $\left(t_{1 / 2}\right)$ than soil microcosms amended with NPK fertilizer and unamended soil (natural attenuation) remediation system. The biodegradation rate constant and estimated biostimulation efficiency values showed that among the crop and animal-derived organic wastes used alone and in combinations, pig dung suggest to offer the best biostimulation performance, which was closely followed by the combination of pig dung and cassava peels. The system proposed here is inexpensive, efficient, and environmentally friendly and may thus offer a viable choice for petroleum hydrocarbons-contaminated soil remediation.
\end{abstract}

Keywords: Bioremediation; Biodegradation; Organic wastes; Firstorder kinetics; Half-life

\section{Introduction}

Crude oil is an extremely complex mixture of aliphatic and aromatic hydrocarbons that causes a variety of risks when released into the environment. It is physically, chemically and biologically harmful to soil because of the presence of many toxic compounds, such as polycyclic aromatic hydrocarbons, benzene and its substituted cycloalkane rings, in relatively high concentrations. This oil can cause chronic sub-acute toxicological effect (reduced growth and reproduction, poor health, low recruitment rates), which can alter population dynamics and disrupt tropic interactions and the structure of natural communities within ecosystems [1]. The fate and effects of spilled crude oil and its products in soils have already been the subject of several studies [2,3]. Biodegradation of hydrocarbon compounds is one of the most important processes involved in the weathering and eventual removal of oil from the environment, particularly for its nonvolatile components. Thus, potentially biodegradation can be used for recovery of sensitive areas such as contaminated shorelines, marshes, and wetlands.

The remediation processes leading to the eventual removal of these petroleum hydrocarbons from the environment involve the trio of physical, chemical and biological alternatives [4]. The Physical and chemical methods are the most widely used procedures for clean-up [5]. However, the physicochemical methods have their limitations $[6,7]$ and these limitations are: they are expensive to implement at full scale, they are not environmentally friendly, their technologies are complex and they lead to destruction of soil texture and characteristics [8]. Furthermore, the physicochemical methods do not always result in complete neutralization of pollutants [9]. Due to limitations of the physicochemical technologies stated above, great deals of literature have reported that bioremediation methods are alternatives and or supplements to these methods [10]. This is because of their cost effectiveness, environmental friendliness, simplicity in technology and conservation of soil texture and characteristics $[7,9,11]$. Bioremediation is the naturally occurring process by which microorganisms transform environmental pollutants into harmless end-products [10].

Application of bioremediation can be more effective where environmental conditions permit microbial growth and activity; its application often involves the manipulation of environmental parameters to allow microbial growth and degradation to proceed at a faster rate [12]. Enhanced bioremediation encompasses a broad continuum of technologies $[13,14]$ which may involve the addition of electron acceptors or electron donors to stimulate naturally occurring microbial populations (biostimulation) or could be the introduction of specific microorganisms (bioaugmentation) to enhance the biodegradation of the target compound. Oil spills result in an imbalance in the carbon-nitrogen ratio at the spill site, because crude oil is essentially a composition of carbon and hydrogen [15]. This cause's nitrogen and phosphorus limitation in an oil-soaked soil, which retards

*Corresponding author: Samuel E Agarry, Department of Chemical Engineering, Ladoke Akintola University of Technology, P. M. B. 4000, Ogbomoso-llorin Road, Ogbomoso, Oyo State, 260001, Nigeria, Tel: +2348055529705; E-mail: sam_agarry@yahoo.com

Received January 25, 2013; Accepted March 07, 2013; Published March 14 2013

Citation: Agarry SE, Aremu MO, Aworanti OA (2013) Kinetic Modelling and HalfLife Study on Enhanced Soil Bioremediation of Bonny Light Crude Oil Amended with Crop and Animal-Derived Organic Wastes. J Pet Environ Biotechnol 4: 137. doi:10.4172/2157-7463.1000137

Copyright: (c) 2013 Agarry SE, et al. This is an open-access article distributed under the terms of the Creative Commons Attribution License, which permits unrestricted use, distribution, and reproduction in any medium, provided the original author and source are credited. 
the growth of bacteria and the utilization of carbon source $(s)[15,16]$. Microbes and nutrients have been identified as one of the various factors that may limit the rate of petroleum hydrocarbon degradation. Thus, bioremediation technologies have been developed for soils and coastal areas using the addition of nutrients and microbes [1719]. Biostimulation can be considered as an appropriate remediation technique for crude oil removal in soil and requires the evaluation of both the intrinsic degradation capacities of the autochthonous microflora and the environmental parameters involved in the kinetics of the in situ process [20].

Kinetics of bioremediation process can be evaluated in two ways: (i) factors influencing the amount of degraded compounds with time and (ii) the types of curves that describes the degradation and determines which of them fits the degradation of the given compounds by the microbial culture [21]. Bioremediation kinetic studies in a natural environment are often empirical, reflecting only the basic knowledge about the microbial density and its activity in the given environment [22]. The prediction of petroleum hydrocarbons biodegradation kinetics is difficult and complicated in most cases due to the fact that different components of crude oil such as aliphatic, aromatic and polycyclic compounds have different degradation rates $[23,24]$. This is why lighter crude oils (higher API gravity) normally have a faster biodegradation than heavy crude oils. Furthermore, variations in biokinetic constants have been reported for biodegradation of petroleum hydrocarbons carried out in the same conditions [25] and this may be due to differences in experimental techniques or data analysis [26]. Nevertheless, kinetics is still essential to determine the speed of reaction and control of the process in hydrocarbon biodegradation studies; however, there is still a very limited knowledge on the subject of bioremediation kinetics of petroleum hydrocarbons.

Biostimulation in systems controlling different physical and chemical factors has been well documented [26-28]. The addition of inorganic or organic nitrogen-rich nutrients (biostimulation) is an effective approach to enhance the bioremediation process [29]. Walworth et al. [30] examined the effects of nitrogen and phosphorus addition on phenanthrene hydrocarbon biodegradation in four soils and found that phenanthrene biodegradation rates were related to the initial nitrogen and phosphorus concentrations in the soils. Mills and Frankenberger [31] evaluated the effect of phosphorus sources and concentration (100-1000 mg/kg) on diesel fuel degradation, and reported that degradation depended on phosphorus availability. Some sources might supply enough phosphorus to restore the microbial C/P relationship, but become unavailable because of their low solubility. Positive effects of nitrogen amendment using nitrogenous fertilizer on microbial activity and/or petroleum hydrocarbon degradation have been widely demonstrated $[32,33]$. On the other hand, Seklemova et al. [34] found that the addition of nutrients had no effect on the decontamination of a forest soil contaminated with diesel oil. Nevertheless, addition of nutrients including nitrogen and phosphorus is a standard practice for increasing hydrocarbon degradation [35]. By adding these nutrients, the $\mathrm{C} / \mathrm{N}$ and $\mathrm{C} / \mathrm{P}$ ratios of the soil are closer to the bacterial $\mathrm{C} / \mathrm{N}$ and $\mathrm{C} / \mathrm{P}$ requirements. However, in developing countries, inorganic chemical fertilizers are costly as well as not sufficient for agriculture, let alone for cleaning oil spills. It therefore necessitates the search for cheaper and environmentally friendly options of enhancing petroleum hydrocarbon degradation. One of such option is the use of crop- derived organic wastes (crop residue) and animal derived organic wastes (animal dung) that act as bulking agents and also as bacterial biomass suppliers. This improves the aeration condition in the bioremediation process [20]
There are no adequate literatures on the potential use of these crop residues and animal wastes as biostimulating agents. However, few workers have investigated the potential use of these crop residue organic wastes such as corn residues and sugarcane bagasse [20], banana skin [36], spent brewery grain [36], rice husk and coconut shell [37] and animal wastes like cow dung [38], pig dung [39,40], poultry manure $[40,41]$ and goat dung [40] as biostimulating agents in the cleanup of soil contaminated with petroleum hydrocarbons and were found to show positive influence on petroleum hydrocarbon biodegradation in a polluted environment. Nevertheless, the search for cost effective and environmentally friendly methods of petroleum hydrocarbon removal from contaminated sites still needs to be further investigated, since in developing countries, inorganic chemical fertilizers are costly $[42,43]$ as well as not sufficient for agriculture, let alone for cleaning oil spills. According to Alexandratos [44] and OECD [45], Western Europe uses more chemical fertilizer than almost any other nation in the world due to heavy subsidies from the government and that they uses livestock manure and crop residues to provide almost half of all external nutrient inputs [46] as well as to improve the soil physicochemical properties. However, to the best of our knowledge there is a dearth of information on the use of protein-based crop residues such as beans shell, melon shell and groundnut shell and carbohydrate based-crop residue such as cassava peels as biostimulating or amendment agents for enhanced bioremediation of petroleum hydrocarbons-contaminated soil. Furthermore, the evaluation and comparison of crop-derived organic wastes (crop residues) and animal-derived organic wastes (animal dung) has not been reported in the literature.

Therefore, the objective of this study is to determine the biostimulation potential of crop-derived organic wastes (beans shell, cassava peels, groundnut shell and melon shell) and animal-derived organic wastes (cow dung and pig dung) in the enhancement of crude oil (petroleum hydrocarbon) biodegradation in soil. The degradation kinetics of Bonny light crude oil in soil with respect to the organic wastes amended soil and unamended soil were determined and modeled using first-order kinetic model.

\section{Methods}

\section{Collection of samples}

The soil sample used for the study was collected from the top surface soil $(0-15 \mathrm{~cm})$ of Ladoke Akintola University of Technology (LAUTECH) agricultural farm land, Ogbomoso, Nigeria. The soil samples were air dried, homogenized, passed through a $2-\mathrm{mm}$ (pore size) sieve and stored in a polyethylene bag and kept in the laboratory prior to use. The Bonny light crude oil (API, 31.2 and density, 0.8694 $\mathrm{kg} / \mathrm{l}$ ) was obtained from Nigerian National Petroleum Corporation, Port Harcourt, Nigeria. It was weathered by exposure to the atmospheric condition from 10.00 am to $4.00 \mathrm{pm}$ for two weeks with occasional stirring after which it was stored for further use. NPK fertilizer (20:10:10) was purchased from an agro-chemical store, Ogbomoso, Nigeria. The Cow Dung (CD) was collected from a cow market in Ogbomoso, Nigeria. The Pig Dung (PD) was obtained from the piggery farm of LAUTECH, Ogbomoso, Nigeria. The Groundnut Shells (GS), Melon Shell (MS) and Beans Shell (BS) were obtained from a mill in Saja Area of Ogbomoso, Nigeria. The Cassava Peels (CP) was obtained from a cassava market in Ogbomoso, Nigeria. The entire different amendment agent was each sun dried for two weeks, ground and sieved to obtain uniform size particles. Each amendment agent was stored in a polyethylene bag and kept prior to use. The sanitary measures taken include the methods of collection, storage, handling, and distribution/ application of the animal dung in the soil. Hand gloves were used 
Citation: Agarry SE, Aremu MO, Aworanti OA (2013) Kinetic Modelling and Half-Life Study on Enhanced Soil Bioremediation of Bonny Light Crude Oil Amended with Crop and Animal-Derived Organic Wastes. J Pet Environ Biotechnol 4: 137. doi:10.4172/2157-7463.1000137

during collection, storage and application in soil. Hand shovel was used for collection and package into polyethylene bag. Animal dung packaged in polyethylene bag was covered with aluminum foil. Iron rod was used for mixing of the dung and the contaminated soil.

\section{Characterization of soil sample and amendment agents}

The soil sample and amendment agents were characterized for total carbon (TOC), total nitrogen (N), total phosphorus, moisture content, and $\mathrm{pH}$ according to standard methods. The $\mathrm{pH}$ was determined according to the modified method of McLean [47]; total organic carbon was determined by the modified wet combustion method [48] and total nitrogen was determined by the semi-micro-Kjeldhal method [49]. Available phosphorus was determined by Brays No. 1 method [50] and moisture content was determined by the dry weight method. The Total Hydrocarbon Degrading Bacteria (THDB) populations were determined by the vapor phase transfer method [51]. The physicochemical characterized parameters are presented in Table 1.

\section{Solid-phase experimental design and soil treatment}

Soil samples ( $1 \mathrm{~kg}$ ) was put into 20 different plastic bins (microcosm) with a volume of about $3 \mathrm{~L}$ and labeled $\mathrm{A}$ to $\mathrm{T}$, respectively. The soil in each plastic bins was spiked with $10 \%(\mathrm{w} / \mathrm{w})$ weathered Bonny light crude oil (WBLCO) and thoroughly mixed together to achieve complete artificial contamination. 10\% spiking was adopted in order to achieve severe contamination because above $3 \%$ concentration, oil has been reported to be increasingly deleterious to soil biota and crop growth [52]. The soil C:N ratio in each microcosm was adjusted by the addition of $200 \mathrm{~g}$ each (as single and/or in combination) of Cow Dung (CD), Pig Dung (PD), Beans Shell (BS), cassava peel (CP), Groundnut Shell (GS), Melon Shell (BS), and NPK fertilizer, respectively, as nitrogen source (Table 2) and thoroughly mixed. It was assumed that the aforementioned quantities of the crop and animal-derived organic wastes and NPK fertilizer applied to the relevant treatment microcosms were well worked to at least $15 \mathrm{~cm}$ depth in each plastic bin.

Thus, the equivalents of $5000 \mathrm{~kg}$ per hectare of each amendment agents as single or in combinations were applied to each microcosm, respectively. These amounts of each organic waste supplied different amount of $\mathrm{kg}$ nitrogen per hectare (Table 2). The moisture content was adjusted to $50 \%$ water holding capacity by the addition of sterile distilled water and incubated at room temperature $\left(28 \pm 2^{\circ} \mathrm{C}\right)$. The content of each bin was tilled twice a week for aeration, and the moisture content was maintained at $50 \%$ water holding capacity. Plastic bin A with soil and weathered crude oil without amendment agents served as control 1 while Plastic bin T with soil and weathered crude oil amended with NPK fertilizer served as control 2. The experiment was set up in triplicate. In total, 60 microcosms were settled and incubated for six weeks (42 days). Periodic sampling from each plastic bin was carried out at 7-day intervals for 42 days to determine the residual Total Petroleum Hydrocarbon (TPH).

\section{Total petroleum hydrocarbon determination}

The Total Petroleum Hydrocarbon (TPH) content of the soil samples was determined gravimetrically by solvent extraction method of Adesodun and Mbagwu [53]. Soil samples (approximately $10 \mathrm{~g}$ )

\begin{tabular}{|c|c|c|c|c|c|c|c|}
\hline Parameter & Soil & GS & MS & BS & $\mathrm{CP}$ & CD & PD \\
\hline Organic carbon (\%) & $1.05 \pm 0.01$ & $1.99 \pm 0.02$ & $1.96 \pm 0.01$ & $2.79 \pm 0.02$ & $1.86 \pm 0.01$ & $3.13 \pm 0.01$ & $2.94 \pm 0.03$ \\
\hline Total nitrogen (\%) & $0.77 \pm 0.03$ & $1.13 \pm 0.02$ & $0.60 \pm 0.04$ & $1.00 \pm 0.02$ & $1.23 \pm 0.03$ & $2.17 \pm 0.01$ & $3.33 \pm 0.01$ \\
\hline Phosphorus (\%) & $0.06 \pm 0.02$ & $0.10 \pm 0.02$ & $0.09 \pm 0.03$ & $0.36 \pm 0.01$ & $0.13 \pm 0.02$ & $0.25 \pm 0.03$ & $0.12 \pm 0.04$ \\
\hline $\mathrm{Ph}$ & $7 \pm 0.1$ & $7.6 \pm 0.2$ & $7 \pm 0.1$ & $4.8 \pm 0.2$ & $4.4 \pm 0.1$ & $8.4 \pm 0.2$ & $7.9 \pm 0.1$ \\
\hline Moisture (\%) & $11.4 \pm 0.02$ & $5.2 \pm 0.03$ & $4.8 \pm 0.02$ & $5.0 \pm 0.03$ & $6.3 \pm 0.02$ & $8.4 \pm 0.02$ & $8.8 \pm 0.01$ \\
\hline
\end{tabular}

Note: Each value is a mean of three replicates and \pm indicates standard deviation among them.

GS: Groundnut Shell; MS: Melon Shell; BS: Beans Shell; CP: Cassava Peels; CD: Cow Dung; PD: Pig Dung

Table 1: Soil sample and organic wastes physical and chemical analysis.

\begin{tabular}{|c|c|c|}
\hline Microcosm code & Biostimulation agents and amount used & C:N \\
\hline A & Unamended control soil (natural attenuation) & \\
\hline $\mathrm{B}$ & Cow dung $(C D)$ & $19: 1$ \\
\hline $\mathrm{C}$ & Pig dung (PD) & $13: 1$ \\
\hline $\mathrm{D}$ & Cassava peels $(\mathrm{CP})$ & $34: 1$ \\
\hline$E$ & Melon shell (MS) & $69: 1$ \\
\hline $\mathrm{F}$ & Beans shell (BS) & $42: 1$ \\
\hline G & Groundnut shell (GS) & $37: 1$ \\
\hline $\mathrm{H}$ & $100 \mathrm{~g}$ Cow dung (CD) +100 g Groundnut shell (GS) & $25: 1$ \\
\hline 1 & $100 \mathrm{~g}$ Cow dung (CD)+100 g Melon shell (MS) & $30: 1$ \\
\hline J & $100 \mathrm{~g}$ Cow dung (CD)+100 g Cassava peels (CP) & $24.5: 1$ \\
\hline $\mathrm{K}$ & $100 \mathrm{~g}$ Pig dung (PD)+100 g Beans shell (BS) & $19: 1$ \\
\hline $\mathrm{L}$ & $100 \mathrm{~g}$ Pig dung (PD)+100 g Groundnut shell (GS) & $18.7: 1$ \\
\hline M & 100 g Pig dung (PD)+100 g Cassava peels (CP) & $18: 1$ \\
\hline $\mathrm{N}$ & $100 \mathrm{~g}$ Groundnut shell (GS)+100 g Cassava peels (CP) & $35: 1$ \\
\hline $\mathrm{O}$ & $100 \mathrm{~g}$ Beans shell $(\mathrm{BS})+100 \mathrm{~g}$ Cassava peels $(\mathrm{CP})$ & $38: 1$ \\
\hline $\mathrm{P}$ & 100 g Cow dung (CD)+100 g Pig dung (PD) & $15: 1$ \\
\hline Q & $100 \mathrm{~g}$ Groundnut shell (GS) +100 g Beans shell (BS) & $39: 1$ \\
\hline $\mathrm{R}$ & $100 \mathrm{~g}$ Groundnut shell (GS)+100 g Melon shell (MS) & $48: 1$ \\
\hline $\mathrm{S}$ & $100 \mathrm{~g}$ Beans shell (BS)+100 g Melon shell (MS) & $52: 1$ \\
\hline $\mathrm{T}$ & $1.75 \mathrm{~g} \mathrm{NPK}$ fertilizer & $46: 1$ \\
\hline
\end{tabular}

Table 2: Types of organic wastes and their combinations in different microcosms. 
was taken from each microcosm and put into a 50-ml flask and 20 $\mathrm{ml}$ of $\mathrm{n}$-hexane was added. The mixture was shaken vigorously on a magnetic stirrer for $30 \mathrm{~min}$ to allow the hexane extract the oil from the soil sample. The solution was then filtered using a Whatman filter paper and the liquid phase extract (filtrate) diluted by taking $1 \mathrm{ml}$ of the extract into $50 \mathrm{ml}$ of hexane. The absorbance of this solution was measured spectrophotometrically at a wavelength of $400 \mathrm{~nm}$ $\mathrm{HACH}$ DR/2010 Spectrophotometer using n-hexane as blank. The total petroleum hydrocarbon in soil was estimated with reference to a standard curve derived from fresh crude oil of different concentration diluted with $\mathrm{n}$-hexane. Percentage degradation (D) was calculated using the following formula:

$$
D=\frac{T P H_{i}-T P H_{r}}{T P H_{i}} \times 100
$$

where $\mathrm{TPH}_{\mathrm{i}}$ and $\mathrm{TPH}$ are the initial and residual $\mathrm{TPH}$ concentrations, respectively.

\section{Dehydrogenase activity determination}

Soil microbial activity was estimated by the dehydrogenase assay. Dehydrogenase activity was determined by monitoring the rates of reduction of 2,3,5-triphenyltetrazolium chloride to triphenylformazan as described by Alef [54], calculated as $1 \mathrm{~g}$ of formazan per gram of soil after one day ( $24 \mathrm{~h})$, and expressed as relative activity (\%) in relation to the control activity (100\%).

\section{Data analysis}

The data were subjected to one-way analysis of variance (ANOVA) at $5 \%$ probability. Mean of the different treatments were tested for level of significant differences at $\mathrm{p}<0.05$ by Tukey (Honestly Significant Difference) test. The data analysis was performed using statistical package for social sciences, version 16.0 (SPSS Inc., Chicago, IL, USA).

\section{Bioremediation kinetics}

Kinetic analysis is a key factor for understanding biodegradation process, bioremediation speed measurement and development of efficient clean up for a crude oil contaminated environment. The information on the kinetics of soil bioremediation is of great importance because it characterizes the concentration of the contaminant remaining at any time and permit prediction of the level likely to be present at some future time. Biodegradability of crude oil is usually explained by first order kinetics $[22,23,37]$ and this is given as in Eq. (2) :

$$
C_{t}=C_{o} e^{-k t}
$$

where $C_{o}$ is the initial TPH content in soil $(\mathrm{mg} / \mathrm{kg}), C_{t}$ is the residual TPH content in soil at time $t,(\mathrm{mg} / \mathrm{kg}), k$ is the biodegradation rate constant $\left(\right.$ day $\left.^{-1}\right)$ and $t$ is time (day). Plotting the logarithm of TPH concentration versus time presents appropriate information about the biodegradation rate.

\section{Estimation of biodegradation half-life times}

The biological half-life is the time taken for a substance to lose half of its amount. Biodegradation half-lives are needed for many applications such as chemical screening [55], environmental fate modeling [56] and describing the transformation of pollutants $[57,58]$. Biodegradation half life times $\left(t_{1 / 2}\right)$ are calculated by Eq. (3) [24,56,57]:

$$
t_{1 / 2}=\frac{\ln 2}{k}
$$

where $k$ is the biodegradation rate constant $\left(\right.$ day $\left.^{-1}\right)$. The half life model is based on the assumption that the biodegradation rate of hydrocarbons positively correlated with the hydrocarbon pool size in soil [59].

\section{Results and Discussion}

\section{Removal of total petroleum hydrocarbons and microbial growth}

The level of biodegradation of WBLCO in soil amended with crop residues and animal dung wastes (alone and in combination) are shown in Figures 1-4, respectively. Figure 1 shows the degradation profile of crude oil and growth profile of THDB in soil amended alone with CD, PD, CP, MS, BS, GS, and NPK fertilizer, respectively. There was a rapid TPH reduction (Figure 1a) with corresponding rapid growth of the THDB (Figure 1c) due to increased microbial activity (Figure 1b) within the first 21 days of the study in all the amended soil (biostimulation) compared to that of unamended soil (natural attenuation). At the end of the 21 days, there was $90.2 \%, 89.3 \%, 88.5 \%$, $88 \%, 87.9 \%, 86.9 \%$, and $85 \%$ TPH reduction in soil amended with PD, CD, GS, MS, CP, BS, and NPK fertilizer, respectively, while 55.6\% TPH reduction was observed in unamended soil (natural attenuation). However, at the end of remediation period (day 42 ), there was $96.6 \%$, 94.9\%, 93.8\%, 93.5\%, 93.1\%, 92.7\%, and 90.8\% TPH reduction in soil.
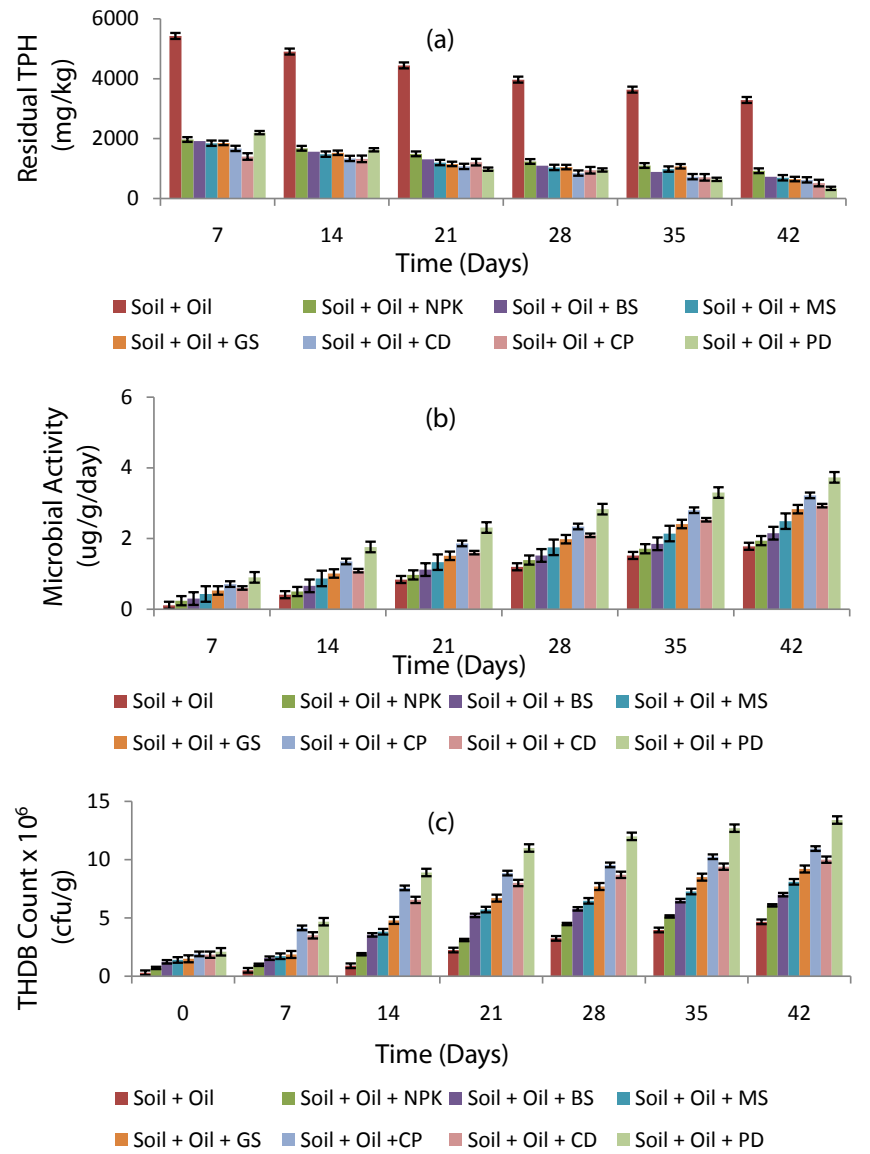

Figure 1: (a) Degradation profile, (b) Microbial activity and (c) Growth profile of THDB for the biodegradation of WBLCO in soil microcosms amended with NPK, BS, MS, GS, CP, CD, PD and unamended soil microcosm (natura attenuation). Bars indicate the average of triplicate samples while the error bars show the standard deviation. 
During this period, microbial activity increased by $3.73,3.22,2.93$, $2.83,2.49,2.15$, and 1.7 fold (Figure $1 \mathrm{~b}$ ) with a corresponding increase in THDB growth from 2.1 to $13.4 \times 10^{6} \mathrm{cfu} / \mathrm{g}, 1.85$ to $10 \times 10^{6} \mathrm{cfu} / \mathrm{g}$, 1.92 to $10.95 \times 10^{6}, 1.5$ to $9.2 \times 10^{6} \mathrm{cfu} / \mathrm{g}, 1.4$ to $8.1 \times 10^{6} \mathrm{cfu} / \mathrm{g}, 1.24$ to $7 \times 10^{6} \mathrm{cfu} / \mathrm{g}$, and 0.715 to $6.08 \times 10^{6} \mathrm{cfu} / \mathrm{g}$ in soil amended with $\mathrm{PD}, \mathrm{CP}, \mathrm{CD}, \mathrm{GS}, \mathrm{MS}, \mathrm{BS}$, and NPK fertilizer, respectively. At the end of day $42,67.1 \%$ TPH reduction with a THDB growth increase from 0.3 to $4.67 \times 10^{6} \mathrm{cfu} / \mathrm{g}$ was observed in the unamended soil (natural attenuation). The biodegradation profiles of crude oil contaminated soil amended with two level combinations of crop residues and/or animal dung wastes $(\mathrm{PD}+\mathrm{CP}, \mathrm{CD}+\mathrm{GS}, \mathrm{CD}+\mathrm{MS}, \mathrm{CD}+\mathrm{CP}, \mathrm{PD}+\mathrm{BS}$ and $\mathrm{PD}+\mathrm{GS}$ ) are shown in Figure 2-4, respectively. A rapid TPH reduction was observed within the first 21 days for each combination treatment. During this period, there was $91.96 \%, 90.86 \%, 90.92 \%, 89.45 \%, 92.58 \%$ and $86.61 \%$ TPH reduction in soil amended with $\mathrm{PD}+\mathrm{CP}, \mathrm{CD}+\mathrm{GS}$, $\mathrm{CD}+\mathrm{MS}, \mathrm{CD}+\mathrm{CP}, \mathrm{PD}+\mathrm{BS}$ and $\mathrm{PD}+\mathrm{GS}$, respectively (Figure 2a). Also, at the end of day $21,85 \%$ and $55.6 \% \mathrm{TPH}$ reduction was observed in soil amended with NPK fertilizer and unamended control soil (natural attenuation), respectively. Within these 21 days of remediation, an increase in microbial activity (Figure 2b) and a corresponding increase in THDB growth (Figure 2c) in soil amended with PD+CP, CD+GS, $\mathrm{CD}+\mathrm{MS}, \mathrm{CD}+\mathrm{CP}, \mathrm{PD}+\mathrm{BS}$ and $\mathrm{PD}+\mathrm{GS}$ were observed. However, at the
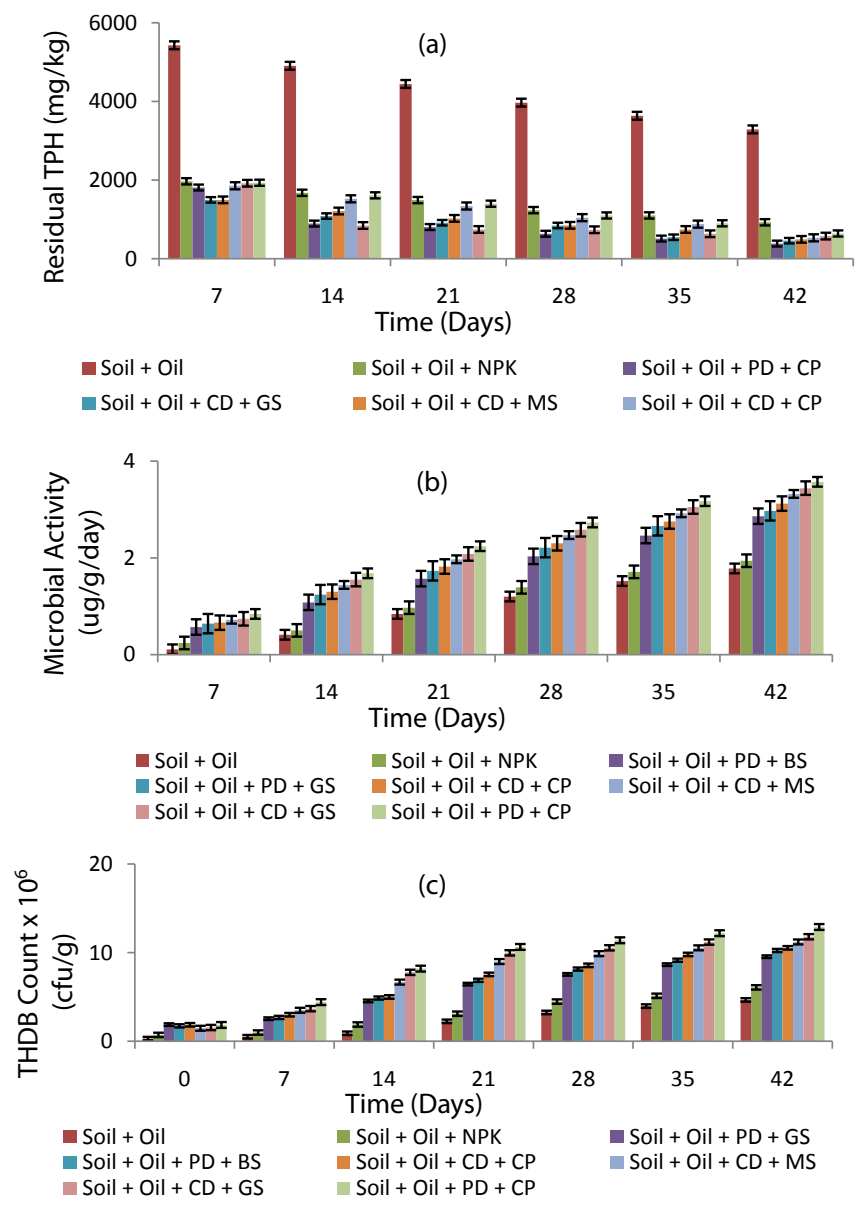

Figure 2: (a) Degradation profile, (b) Microbial activity and (c) Growth profile of THDB for the biodegradation of WBLCO in soil microcosms amended with NPK, PD+GS, PD+BS, CD+CP, CD+MS, CD+GS, PD+CP and unamended soil microcosm (natural attenuation). Bars indicate the average of triplicate samples while the error bars show the standard deviation.
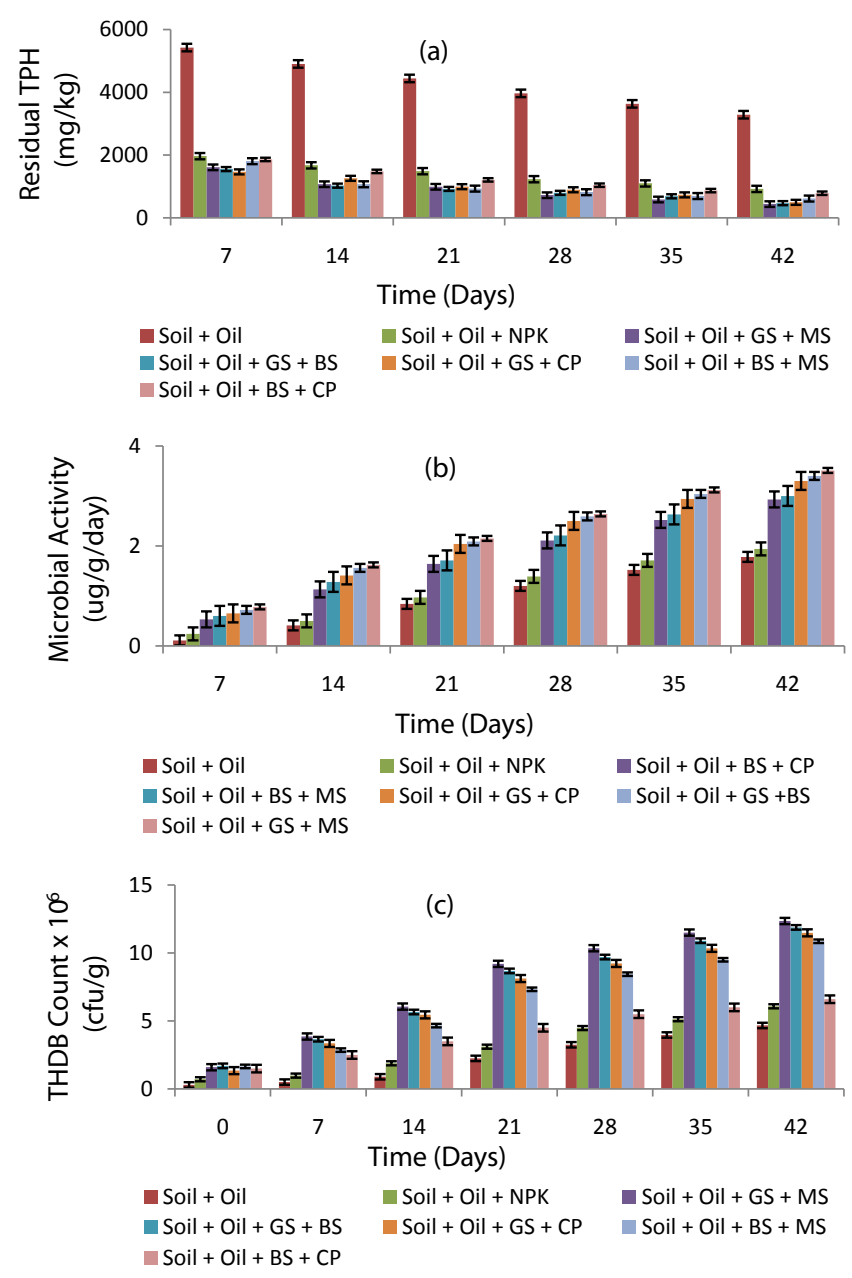

Figure 3: (a) Degradation profile, (b) Microbial activity and (c) Growth profile of THDB for the biodegradation of WBLCO in soil microcosms amended with NPK, GS+MS, GS+BS, GS+CP, BS+MS, BS+CP and unamended soil microcosm (natural attenuation). Bars indicate the average of triplicate samples while the error bars show the standard deviation.

end of day 42 remediation trial, 96.18\%, 95.42\%, (95.19\%), 94.44\%, 94.26\% and $93.59 \% \mathrm{TPH}$ reductions were observed for WBLCO contaminated soil amended with $\mathrm{PD}+\mathrm{CP}, \mathrm{CD}+\mathrm{GS}, \mathrm{CD}+\mathrm{MS}, \mathrm{CD}+\mathrm{CP}$, $\mathrm{PD}+\mathrm{BS}$ and $\mathrm{PD}+\mathrm{GS}$, respectively (Figure 2a). Furthermore, increase in microbial activity by $2.86,2.97,3.12,3.32,3.44$ and 3.57 fold (Figure 2b) with a corresponding increase in THDB growth from 1.84 to 12.9 $\times 10^{6} \mathrm{cfu} / \mathrm{g}, 1.55$ to $11.8 \times 10^{6} \mathrm{cfu} / \mathrm{g}, 1.47$ to $11.21 \times 10^{6} \mathrm{cfu} / \mathrm{g}, 1.86$ to $10.55 \times 10^{6} \mathrm{cfu} / \mathrm{g}, 1.74$ to $10.25 \times 10^{6} \mathrm{cfu} / \mathrm{g}$ and 1.88 to $9.55 \times 10^{6} \mathrm{cfu} / \mathrm{g}$ (Figure 2c) was observed at the end of day 42 remediation period for soil amended with $\mathrm{PD}+\mathrm{CP}, \mathrm{CD}+\mathrm{GS}, \mathrm{CD}+\mathrm{MS}, \mathrm{CD}+\mathrm{CP}, \mathrm{PD}+\mathrm{BS}$ and $\mathrm{PD}+\mathrm{GS}$, respectively.

The degree of biodegradation of WBLCO in soil amended with two level combinations of crop residues (GS+MS, GS+BS, BS+MS, $\mathrm{GS}+\mathrm{CP}$ and $\mathrm{BS}+\mathrm{CP}$ ) also showed that there was a similar rapid TPH reduction within the first 21 days of which there was $95.59 \%, 95.29 \%$, 93.82\%, 90.04\% and $87.88 \%$ TPH reduction in soil amended with $\mathrm{GS}+\mathrm{MS}, \mathrm{GS}+\mathrm{BS}, \mathrm{BS}+\mathrm{MS}, \mathrm{GS}+\mathrm{CP}$ and $\mathrm{BS}+\mathrm{CP}$, respectively. At the end of remediation trial period (day 42 ), the WBLCO contaminated soil amended with GS+MS had the highest TPH reduction $(95.59 \%)$ which was closely followed by GS+BS (95.29\%), BS+MS (93.82\%), 


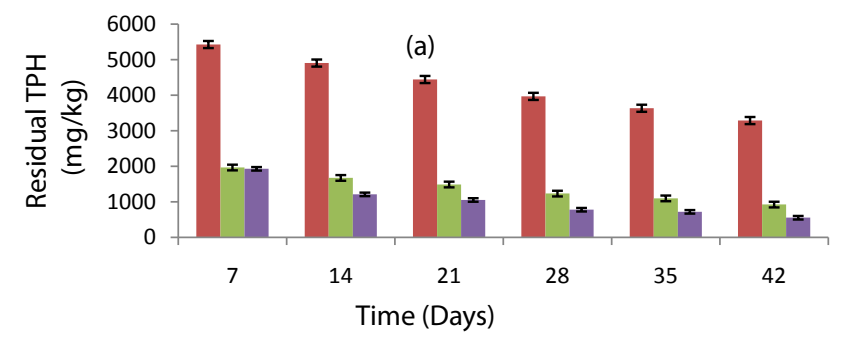

- Soil + Oil $\quad$ Soil + Oil + NPK $\quad$ Soil + Oil + CD + PD
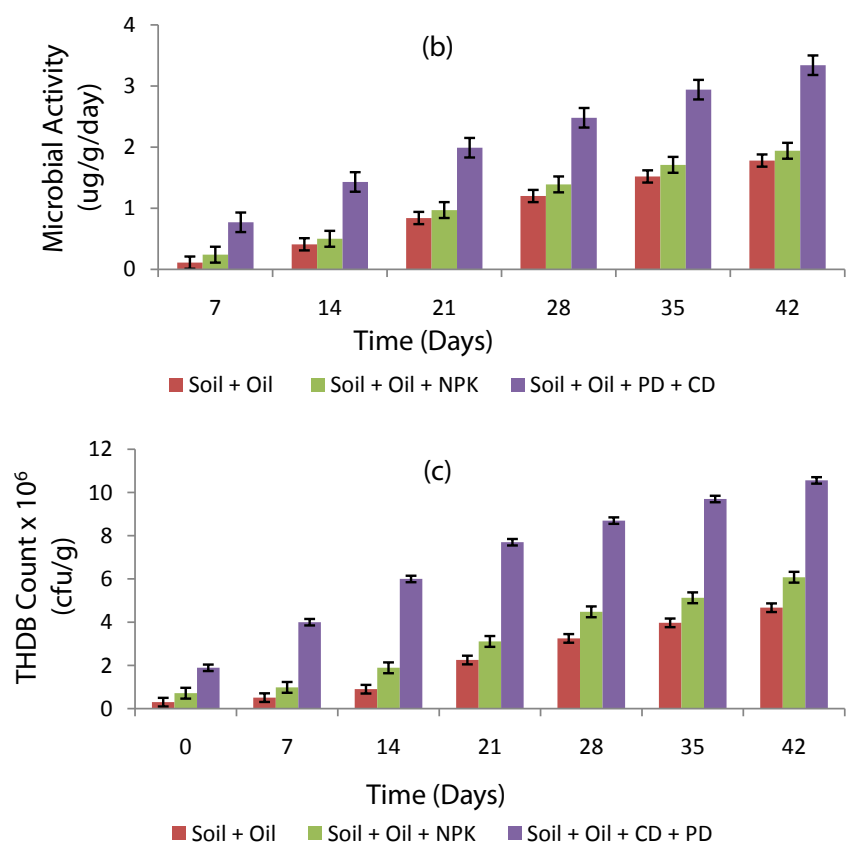

Figure 4: (a) Degradation profile, (b) Microbial activity, and (c) Growth profile of THDB for the biodegradation of WBLCO in soil microcosms amended with NPK, CD+PD and unamended soil microcosm (natural attenuation). Bars indicate the average of triplicate samples while the error bars show the standard deviation.

$\mathrm{BS}+\mathrm{CP}(92.13 \%) \mathrm{GS}+\mathrm{CP}(92.13 \%)$ and $\mathrm{BS}+\mathrm{CP}(92.13 \%)$ as compared to $90.8 \%$ and $67.1 \%$ TPH reduction in NPK fertilizer amended soil and unamended control soil (natural attenuation), respectively (Figure 3a). Also, at the end of day 42 remediation period there was an increase in the microbial activity by $2.93,3.00,3.30,3.40$ and 3.51 fold with a corresponding increase in the growth of THDB from 1.6 to $12.35 \times 10^{6}$ $\mathrm{cfu} / \mathrm{g}, 1.7$ to $11.88 \times 10^{6} \mathrm{cfu} / \mathrm{g}, 1.35$ to $11.48 \times 10^{6} \mathrm{cfu} / \mathrm{g}, 1.66$ to 10.86 $\times 10^{6} \mathrm{cfu} / \mathrm{g}$ and 1.5 to $6.6 \times 10^{6} \mathrm{cfu} / \mathrm{g}$ in the WBLCO soil microcosms amended with GS+MS, GS+BS, BS+MS, BS+CP, GS+CP and BS+CP, respectively (Figure $3 \mathrm{~b}$ and $3 \mathrm{c}$ ). However, an increase in the microbial activity by 1.67 and 1.70 fold with a corresponding increase in THDB growth from 0.715 to $6.08 \times 10^{6} \mathrm{cfu} / \mathrm{g}$ and 0.30 to $4.67 \times 10^{6} \mathrm{cfu} / \mathrm{g}$ was achieved in soil microcosms amended with NPK fertilizer and unamended soil, respectively.

Figure 4a shows the level of WBLCO biodegradation in soil amended with two level combinations of animal dung waste (CD and PD). It was observed that within the first 21 days of remediation trial there was a fast reduction in TPH and this gradually reduced till the end of remediation period. At the end of day 42 remediation period,
94.44\% TPH reduction was achieved as compared to $90.8 \%$ and $67.1 \% \mathrm{TPH}$ reduction observed in the NPK fertilizer amended and unamended control soil (natural attenuation). During this period there was an increase in microbial activity by 3.34 fold with a corresponding increase in THDB growth from 1.89 to $10.56 \times 10^{6} \mathrm{cfu} / \mathrm{g}$ (Figure $4 \mathrm{~b}$ and $4 \mathrm{c})$.

Therefore, the results depicted in Figures 1-4 revealed that the highest rate of WBLCO degradation was achieved in the first three weeks of remediation. During this period, more than $50 \%$ of the TPH was degraded, with a small and continual decrease in degradation until the end of remediation period (six weeks). Biodegradation of WBLCO was high (92\% to $96.6 \%)$ in all the soil amended with organic wastes compared to the NPK fertilizer amended (90.8\%) and unamended soil (67.1\%). Also, the THDB growth and microbial activity in all the amended (crop and animal-derived organic wastes) soil microcosms (biostimulation) was higher than that of the unamended control soil (natural attenuation). This showed that the soil microcosms amended with the crop and animal-derived organic wastes (alone or in combination) enhanced the microbial growth rate which accounted for the higher bacterial counts and microbial activity observed in all the amended soil microcosms than the unamended soil microcosm (natural attenuation). The higher bacterial count in amended soil microcosms (biostimulation) may be due to high nutrient level (in the form of $\mathrm{N}, \mathrm{P}$ and $\mathrm{K}$ ) provided by the added crop residues and animal dung organic wastes which stimulated increase in the intrinsic bacterial population and activity thus leading to high energy (carbon) demand by the oil-degrading microbes. This has resulted in the higher reduction of total petroleum hydrocarbon (TPH) (i.e., higher WBLCO degradation) in the amended soil microcosms. Similar observations have been reported for the use of the mixture of rice straw and pig dung [60], mixture of cow dung, pig dung and poultry dung [61], cocoa pod husk and plantain peels [62], and mixture of cow dung and poultry litters [63] as amendment or biostimulation agents in the biodegradation of petroleum hydrocarbons in soil.

\section{Evaluation of biodegradation kinetics and half-life}

First-order kinetics model equation (Eq. 2) fitted to the biodegradation data was used to determine the rate of biodegradation of WBLCO in the various remediation treatments which is illustrated in Figures 5-7. The half-life times of WBLCO biodegradation was calculated using Eq. (3). The biodegradation rate constants $(k)$ and halflife times $\left(t_{1 / 2}\right)$ for the different remediation treatments are presented in Table 3. It is to be noted that the higher is the biodegradation rate constants, the higher or faster is the rate of biodegradation and consequently the lower is the half-life times. It could be seen from Table 3 that among the WBLCO soil microcosms amended alone with animal organic waste (CD and PD), the soil microcosm amended with PD had a higher $k\left(0.0498\right.$ day $\left.^{-1}\right)$ and lower $t_{1 / 2}$ (13.9 days) than that amended with $\mathrm{CD}\left(k=0.0266\right.$ day $^{-1}$ and $t_{1 / 2}=26.1$ days $)$. Among the WBLCO soil microcosms amended alone with crop residue organic wastes (CP, GS, MS, and BS), soil microcosm amended with CP had a higher $k\left(0.0288\right.$ day $\left.^{-1}\right)$ and lower $t_{1 / 2}$ (24.1 days) than others. This was closely followed by soil microcosm amended with GS ( $k=0.0260$ day ${ }^{1}$ and $t_{1 / 2}=26.7$ days), MS ( $k=0.0257$ day $^{-1}$ and $t_{1 / 2}=27.0$ days $)$, and BS ( $k=0.0251$ day $^{-1}$ and $t_{1 / 2}=27.6$ days), respectively.

More also, for soil microcosms amended with two level combinations of animal and crop residue organic wastes, the soil microcosm amended with $\mathrm{PD}+\mathrm{CP}$ had a higher $k\left(0.0394 \mathrm{day}^{-1}\right)$ and lower $t_{1 / 2}$ (17.6 days) than other amended soil microcosms. However, this was closely followed by soil microcosm amended with $\mathrm{CD}+\mathrm{GS}$ 

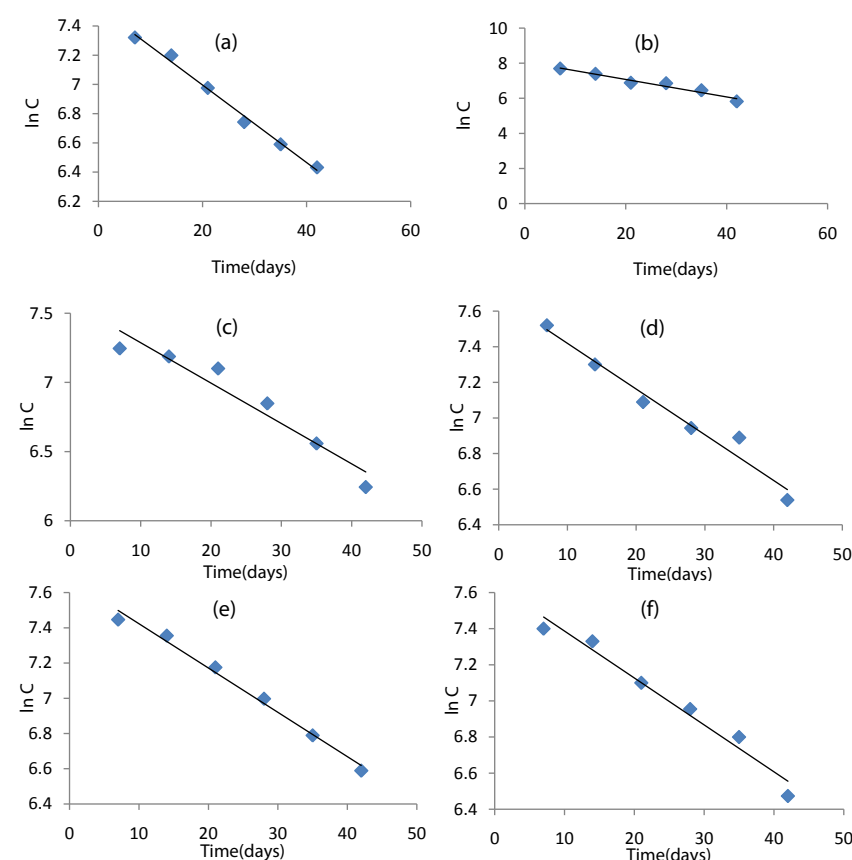

Figure 5: First-order kinetic model fitted to the biodegradation data of WBLCO in soil microcosms amended with (a) CD, (b) PD, (c) CP, (d) MS, (e) BS, and (f) GS.
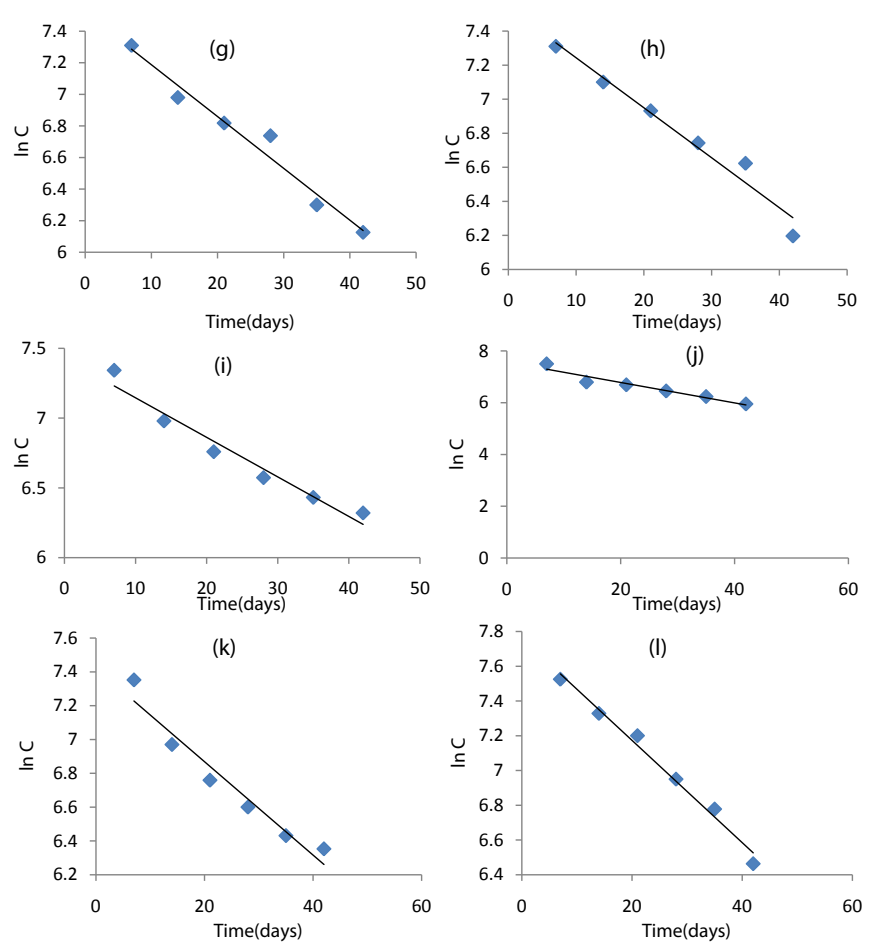

Figure 6: First-order kinetic model fitted to the biodegradation data of WBLCO in soil amended with (g) $C D+G S$, (h) $C D+M S$, (i) $C D+C P$, (j) $P D+C P,(k)$ $P D+B S$, and (I) PD+GS.

$\left(k=0.0328\right.$ day $^{-1} ; t_{1 / 2}=21.1$ days $), \mathrm{CD}+\mathrm{MS}\left(k=0.0296\right.$ day $^{-1} ; t_{1 / 2}=23.4$ days), $\mathrm{CD}+\mathrm{CP}\left(k=0.0283\right.$ day $^{-1} ; t_{1 / 2}=24.5$ days $), \mathrm{PD}+\mathrm{BS}\left(k=0.0277\right.$ day $^{-1}$; $t_{1 / 2}=25.0$ days $)$ and $\mathrm{PD}+\mathrm{GS}\left(k=0.0262 \mathrm{day}^{-1} ; t_{1 / 2}=26.5\right.$ days $)$, respectively.
Furthermore, among the WBLCO soil contaminated microcosms amended with two level combinations of crop residue organic wastes, a higher biodegradation rate constant (with $k=0.0351$ day $^{-1}$ ) and lower half-life times (19.7 days) was attained in the soil microcosm amended with GS+MS than that obtained in other soil microcosms. This was relatively followed by soil microcosm amended with GS+BS $\left(k=0.0299\right.$ day $^{-1} ; t_{1 / 2}=23.2$ days $), \mathrm{GS}+\mathrm{CP}\left(k=0.0291 \mathrm{day}^{-1} ; t_{1 / 2}=23.8\right.$ days $)$, BS+MS $\left(k=0.0270\right.$ day $^{-1} ; t_{1 / 2}=25.7$ days $)$, and BS+CP $\left(k=0.0247\right.$ day $^{-1} ;$ $t_{1 / 2}=28.1$ days), respectively. Nevertheless, WBLCO soil contaminated microcosms amended with two level combination of animal organic wastes $(\mathrm{CD}+\mathrm{PD})$, the biodegradation rate constant $(k)$ and half-life times $\left(t_{1 / 2}\right)$ was found to be 0.0283 day $^{-1}$ and 24.5 days, respectively. The biodegradation rate constant $(k)$ and half-life time $\left(t_{1 / 2)}\right.$ for the WBLCO soil contaminated microcosm amended with NPK fertilizer was found to be 0.0228 day $^{-1}$ and 30.4 days, respectively, and for soil microcosm not amended with either of the animal organic wastes or crop residue organic wastes was obtained to be 0.0144 day $^{-1}$ and 48.1 days, respectively.

Thus, the biodegradation rate constants obtained for the different WBLCO soil contaminated microcosms amended with the animal and crop residue organic wastes either alone or in combinations were higher with lower half-life times than that of soil microcosm amended with NPK fertilizer and the unamended (natural attenuation). These observations indicate that the addition of various crop residues and animal dung (organic wastes) alone or in combinations enhanced TPH
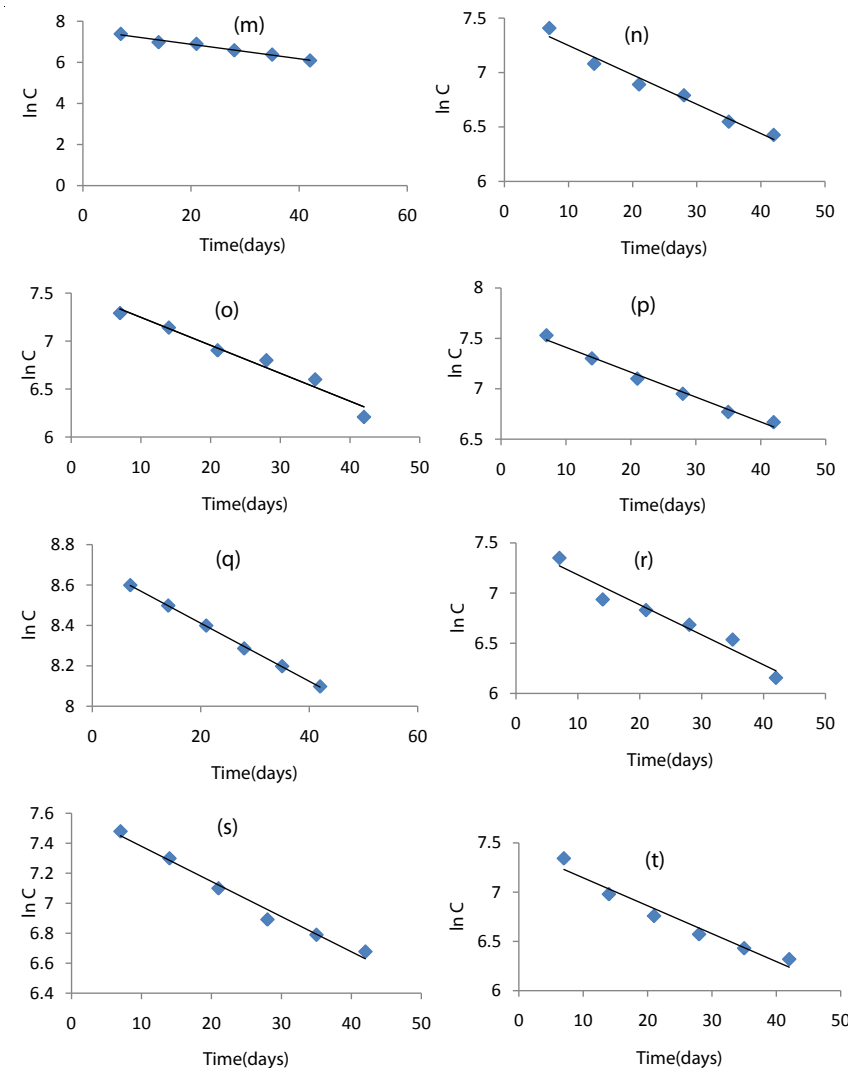

Figure 7: First-order kinetic model fitted to biodegradation data of WBLCO in soil microcosm amended with (m) GS+MS, (n) BS+MS, (o) GS+CP, (p) $B S+C P$, (q) GS+BS, (r) CD+PD, (s) NPK, and (t) unamended soil (natural attenuation). 


\begin{tabular}{|l|c|c|c|}
\hline Biostimulation treatment & $\boldsymbol{k}$ (day $\left.^{-1}\right)$ & $\mathbf{R}^{2}$ & $\boldsymbol{t}_{1 / 2}$ (days) \\
\hline Animal Waste: & 0.0498 & 0.9572 & 13.9 \\
\hline Pig dung & 0.0266 & 0.9926 & 26.1 \\
\hline Cow dung & & & \\
\hline Crop Residue Waste: & 0.0288 & 0.9519 & 24.1 \\
Cassava peel & 0.0260 & 0.9693 & 26.7 \\
Groundnut shell & 0.0257 & 0.9670 & 27.0 \\
Melon shell & 0.0251 & 0.9886 & 27.6 \\
\hline Beans shell & & & \\
\hline Animal and Crop Residue Wastes Combination: & 0.0394 & 0.9306 & 17.6 \\
Pig dung+Cassava peel & 0.0328 & 0.9678 & 21.1 \\
Cow dung+Groundnut shell & 0.0296 & 0.9967 & 23.4 \\
Cow dung+Melon shell & 0.0289 & 0.9588 & 24.0 \\
Cow dung+Cassava peel & 0.0277 & 0.9518 & 25.0 \\
\hline Pig dung+Beans shell & 0.0262 & 0.9962 & 26.5 \\
\hline Pig dung+Groundnut shell & & & \\
\hline Crop Residue Wastes Combination: & 0.0351 & 0.9826 & 19.7 \\
\hline Melon shell+Groundnut shell & 0.0299 & 0.9510 & 23.2 \\
Groundnut shell+Beans shell & 0.0291 & 0.9651 & 23.8 \\
Groundnut shell+Cassava peel & 0.0270 & 0.9730 & 25.7 \\
\hline Melon shell+Beans shell & 0.0247 & 0.9873 & 28.1 \\
\hline Beans shell+cassava peel & & & \\
\hline Animal Wastes Combination: & 0.0283 & 0.9563 & 24.5 \\
\hline Pig dung+Cow dung & & & \\
\hline Inorganic Chemical Fertilizer: & 0.0228 & 0.9820 & 30.4 \\
\hline NPK Fertilizer (20:10:10) & & & \\
\hline Unamended Soil (Control 1) : & 0.0144 & 0.9993 & 48.1 \\
\hline Natural attenuation & & \\
\hline
\end{tabular}

Table 3: The biodegradation rate constants $(k)$ and half-life $\left(t_{1 / 2}\right)$ time of the various treatments.

reduction. However, the variations in the rate constants and half-life times observed in the different organic wastes treatments may be due to the following reasons; firstly, different carbon to nitrogen ratio $(\mathrm{C}: \mathrm{N})$ induced in the contaminated soil by the crude oil and nutrients $(\mathrm{N}$, $\mathrm{P}, \mathrm{K})$ provided by the crop residue and animal-derived organic wastes (Table 2). Zhou and Crawford [64] pointed out that under low nutrient conditions (C:N 300:1) microorganisms did not have enough nutrients for optimal growth; hence rate of biodegradation is low. And, under higher nutrient conditions, i.e., a low C:N ratio (C:N 50:1, 18:1 or 15:1) an optimal microbial growth is likely favored which elicits higher biodegradation rate. Excessive addition of nitrogen (C:N 1.8:1) almost stopped biodegradation, possibly due to ammonia toxicity that inhibited soil microbial growth. Furthermore, Teng et al. [65] have also reported that soil amendment with $\mathrm{C} / \mathrm{N}$ ratio of 10:1 significantly elicited higher polycyclic aromatic hydrocarbon (phenanthrene and (benzo pyrene) biodegradation than those with $\mathrm{C} / \mathrm{N}$ ratio of $25: 1$ and $40: 1$, respectively. Secondly, the source and bioavailability of the nutrients provided by these organic wastes to bacterial species in the oil-polluted soil. Some sources might supply enough nitrogen and phosphorus to restore the microbial $\mathrm{C} / \mathrm{N}$ and $\mathrm{C} / \mathrm{P}$ relationship, but become unavailable because of their low solubility. Knowledge of bioavailability of nutrients is necessary in the planning of an efficient bioremediation strategy [31].

\section{Effectiveness of biostimulation supplements}

A one-way ANOVA analysis was conducted to compare the biodegradation efficiency of the biostimulation or amendment agents and the result is presented in Table 4 . The result suggests that the biostimulation or amendment agents had a statistically significant effect on the biodegradation of WBLCO in soil at the 5\% probability level $(p<0.05)$. The effectiveness of each biostimulation agents was therefore tested. Through evaluation of unamended soil microcosm (natural attenuation) and amended soil microcosm (biostimulation), biostimulant efficiency (B.E) was calculated at the end of the 42- day remediation period using Eq. (4) [23]:

$$
\% B . E=\frac{\% T P H_{(S)}-\% T P H_{(U)}}{\% T P H_{(S)}} \times 100
$$

where, $\% \mathrm{TPH} \mathrm{H}_{(S)}$ is the removal of crude oil in the amended soil, and $\% \mathrm{TPH}_{(v)}$, the removal of crude oil in the unamended soil. The results of B. E are illustrated in Table 5.

As presented in Table 5, each of the biostimulant efficiency (\% B.E) lies between 26.1 and $30.5 \%$. The results in Table 5 generally showed that the biostimulation efficiency of the crop and animalderived organic wastes are marginally and relatively close. Thus, post hoc comparisons using Tukey's (HSD) test at 5\% probability level were carried out to actually determine the significant difference in biodegradation efficiency between any of the biostimulation or amendment agents. The difference in TPH concentration mean between pairs of biostimulation treatments were greater than the HSD value, hence, the grouping of TPH mean using the Tukey's test for the different treatments as presented in Table 6 shows a much significant differences for the bioremediation processes. All the treatments show a significantly different biodegradation rate among them. That is, the Tukey's test revealed that there are significant differences in the biostimulation efficiency between the control (natural attenuation) and NPK fertilizer as well as the crop and animal-derived organic wastes (alone or in combination). It also indicates that there are significant difference in the biostimulation efficiency between the NPK fertilizer and the crop and animal-derived organic wastes (alone or combination) while it further showed that there are significant differences in the biostimulation efficiency of all the crop and animal-derived organic wastes (alone or in combination).

\begin{tabular}{|c|c|c|c|c|c|}
\hline Source & Sum of squares & $\begin{array}{c}\text { Degree of } \\
\text { freedom }\end{array}$ & $\begin{array}{c}\text { Mean of } \\
\text { squares }\end{array}$ & F-value & P-value \\
\hline Treatment & 36813848 & 19 & 1937571 & 10453692 & 0.0000 \\
\hline Error & 14.82784 & 80 & 0.185348 & & \\
\hline Total & 36813863 & 99 & & & \\
\hline
\end{tabular}

Table 4: Analysis of variance (ANOVA) for the different treatments.

\begin{tabular}{|c|c|c|c|}
\hline Microcosm code & Biostimulation treatment & \%degradation & $\mathrm{BE}(\%)$ \\
\hline C & PD & $96.62 \pm 0.44$ & 30.5 \\
\hline M & $P D+C P$ & $96.18 \pm 0.33$ & 30.2 \\
\hline $\mathrm{R}$ & GS+MS & $95.59 \pm 0.24$ & 29.8 \\
\hline $\mathrm{H}$ & $C D+G S$ & $95.42 \pm 0.32$ & 29.7 \\
\hline $\mathrm{P}$ & GS+BS & $95.29 \pm 0.24$ & 29.6 \\
\hline I & $\mathrm{CD}+\mathrm{MS}$ & $95.19 \pm 0.22$ & 29.5 \\
\hline $\mathrm{N}$ & $\mathrm{GS}+\mathrm{CP}$ & $95.03 \pm 0.15$ & 29.4 \\
\hline D & $\mathrm{CP}$ & $94.86 \pm 0.51$ & 29.2 \\
\hline J & $\mathrm{CD}+\mathrm{CP}$ & $94.71 \pm 0.62$ & 29.1 \\
\hline $\mathrm{P}$ & $P D+C D$ & $94.44 \pm 0.25$ & 28.9 \\
\hline $\mathrm{K}$ & PD+BS & $94.26 \pm 0.39$ & 28.8 \\
\hline $\mathrm{S}$ & $\mathrm{BS}+\mathrm{MS}$ & $93.82 \pm 0.23$ & 28.5 \\
\hline B & CD & $93.79 \pm 0.50$ & 28.4 \\
\hline L & PD+GS & $93.59 \pm 0.45$ & 28.3 \\
\hline G & GS & $93.52 \pm 0.27$ & 28.2 \\
\hline $\mathrm{E}$ & MS & $93.08 \pm 0.38$ & 27.9 \\
\hline $\mathrm{F}$ & BS & $92.73 \pm 0.25$ & 27.6 \\
\hline Q & $\mathrm{BS}+\mathrm{CP}$ & $92.13 \pm 0.33$ & 27.1 \\
\hline $\mathrm{T}$ & NPK fertilizer & $90.75 \pm 0.10$ & 26.0 \\
\hline A & $\begin{array}{l}\text { Unamended soil (natural } \\
\text { attenuation) }\end{array}$ & $67.12 \pm 1.08$ & - \\
\hline
\end{tabular}

Table 5: Percentage degradation of crude oil and biostimulant efficiency at the end of six weeks. 


\begin{tabular}{|l|ll|l|l|}
\hline Treatments & $\begin{array}{c}\text { TPH Mean } \\
(\mathbf{m g} / \mathbf{k g})\end{array}$ & $\begin{array}{c}\text { Standard } \\
\text { error }\end{array}$ & Remarks \\
\hline Control (Natural attenuation) & 3286.94 & A & 0.481 & Significant difference \\
\hline NPK fertilizer & 924.99 & B & 0.045 & Significant difference \\
\hline BS+CP & 786.6 & C & 0.145 & Significant difference \\
\hline BS & 727.10 & D & 0.113 & Significant difference \\
\hline MS & 691.21 & E & 0.170 & Significant difference \\
\hline GS & 647.31 & F & 0.119 & Significant difference \\
\hline PD+GS & 640.70 & G & 0.201 & Significant difference \\
\hline CD & 621.18 & H & 0.224 & Significant difference \\
\hline BS+MS & 617.82 & I & 0.105 & Significant difference \\
\hline PD+BS & 574.44 & J & 0.176 & Significant difference \\
\hline PD+CD & 556.24 & K & 0.112 & Significant difference \\
\hline CD+CP & 529.58 & L & 0.275 & Significant difference \\
\hline CP & 514.42 & M & 0.229 & Significant difference \\
\hline GS+CP & 497.17 & N & 0.066 & Significant difference \\
\hline CD+MS & 490.9 & O & 0.098 & Significant difference \\
\hline GS+BS & 471.13 & P & 0.108 & Significant difference \\
\hline CD+GS & 457.69 & Q & 0.144 & Significant difference \\
\hline GS+MS & 440.79 & R & 0.106 & Significant difference \\
\hline PD+CP & 383.74 & S & 0.148 & Significant difference \\
\hline PD & 337.68 & T & 0.200 & Significant difference \\
\hline
\end{tabular}

Table 6: Grouping of TPH mean for the different treatments computed by Tukey's method.

Therefore, between the two different animal dung (CD and PD), PD suggests to be relatively more effective with higher B.E (30.5\%) than CD (28.4\%). Also, between the four different crop residues (GS, MS, BS, and CP), CP suggests to be more effective with a higher B.E (29.2\%) than others. However, it is closely followed by GS (28.2\%), MS (27.9\%), and BS (27.6\%). Furthermore, among the two level combinations of animal and crop residue organic wastes, $\mathrm{PD}+\mathrm{CP}$ suggest to be more effective with higher B.E (30.2\%) than other forms of combination. This is closely and relatively followed by CD+GS (29.7\%), CD+MS (29.5\%), $\mathrm{CD}+\mathrm{CP}(28.9 \%), \mathrm{PD}+\mathrm{BS}(28.8 \%)$, and $\mathrm{PD}+\mathrm{GS}$ (28.3\%), respectively. For the two level combinations of crop residue organic wastes, GS+MS with higher B.E (29.8\%) suggest to be relatively more effective than other combinations. However, this is marginally followed by GS+BS (29.6\%), GS+CP (29.4\%), BS+MS (28.5\%), and BS+CP (27.1\%), respectively. Mean while, the B.E for the two level combination of only animal organic wastes $(\mathrm{CD}+\mathrm{PD})$ is $28.9 \%$ which is lower than that of PD but relatively higher than that of CD. The results in this study suggest that the crop residue and animal-derived organic wastes used as biostimulation agents (alone or in combination) has relative higher biostimulation efficiency in the biodegradation of petroleum hydrocarbons than inorganic (chemical) fertilizer. Moreover, the relative higher efficiency of pig dung, poultry dung and goat dung (animal manure) as biostimulating agents over chemical fertilizer (inorganic nutrient) in the biodegradation of petroleum hydrocarbons in soil has earlier been reported by Agarry et al. [40]. However, this is subject to the amount of animal/plant organic waste and inorganic NPK fertilizer that is being used in the remediation process.

Generally, the difference in the effectiveness (\% B.E) of the various crop and animal-derived organic wastes used alone and/ or in combination as biostimulant in the enhancement of crude oil biodegradation may be attributed to their specific composition, content and the fiber structure. The cellulose, hemi-cellulose, lignin and nitrogen ratio in the different crop residues as well as in the animal dung wastes may be important factors which regulate microorganism growth and activity [66]. Furthermore, Molina-Barahona et al. [20] have reported that the addition of corn and sugarcane bagasse (crop residue) as a biostimulant in a system to remove diesel oil from contaminated soils affected the contaminant degradation efficiency due to the composition of the bulking agent (hemi-cellulose, cellulose, lignin and nitrogen ratio). A similar observation was also reported for the use of sawdust in the removal of oil and grease in a contaminated soil [25].

The addition of bulking agents to soil has been reported to increase oxygen diffusion and mineral nutrient availability as well as carbon source quality and mechanical support surface for bacterial adsorption, and improves soil physicochemical characteristics as to speed up microbial adaptation and selection $[20,25,26,67]$. Thus, in our system, the results suggested that both crop residues (plant organic wastes) and animal dung wastes (animal organic wastes) alone and/or in combination have also contributed to increased oxygen and mineral nutrient availability for the autochthonous microorganisms as a result of the increased microbial activity, increased growth of THDB and the increased TPH reduction that were observed. More also, both the plant and animal organic wastes microbial population supply was also relevant as it may provide additional hydrocarbon degrading microorganisms [67], which could contribute to metabolize hydrocarbon contaminant together with the soil autochthonous microorganisms.

\section{Conclusions}

The present studies confirm that the use of crop residues and animal dung wastes (organic wastes) improved the rate of biodegradation in microcosms simulating soil or land environments contaminated with crude oil. The maximum total petroleum hydrocarbon (TPH) removal of $96.62 \%$ and $94.86 \%$ was obtained for the use of pig dung and cassava peels as biostimulant from the group of animal and crop residue organic wastes, respectively. Furthermore, the most efficient removal of TPH using the various organic wastes alone and/or in combinations occurred within the first 21 days. The biodegradation rate constant obtained from the application of first order kinetics described the rate of crude oil biodegradation with and without biostimulant. The rate constant $(k)$ ranges between 0.0228 day $^{-1}$ and 0.0498 day ${ }^{1}$ for amended soil microcosm and 0.0144 day $^{-1}$ for unamended soil microcosm (natural attenuation). A half-life time $\left(t_{1 / 2}\right)$ of 48.1 days was observed for biodegradation of crude oil in soil not amended with biostimulant. This was reduced to between 13.9 and 29.5 days with the usage of biostimulant in the form of crop residues and animal dung wastes (organic wastes). Statistical analysis using ANOVA and Tukey's test to determine significance effect of the biostimulation agents on WBLCO biodegradation also showed that WBLCO biodegradation in soil was highly influenced by the different crop and animal-derived organic wastes and NPK fertilizer. There was a significant difference in the biostimulation efficiency of the different crop and animal-derived organic wastes (alone or combinations) as well as between the wastes and NPK fertilizer.

From the biostimulation efficiency (\%B.E) and biodegradation rate constant $(k)$ values, the performance of the animal dung and crop residue organic wastes used alone follows this decreasing order: $\mathrm{PD}>\mathrm{CP}>\mathrm{CD}>\mathrm{GS}>\mathrm{MS}>\mathrm{BS}$; while the performance of animal dung and crop residue organic wastes used at two level combinations followed this decreasing order:

$\mathrm{PD}+\mathrm{CP}>\mathrm{GS}+\mathrm{MS}>\mathrm{CD}+\mathrm{GS}>\mathrm{GS}+\mathrm{BS}>\mathrm{CD}+\mathrm{MS}>\mathrm{GS}+\mathrm{CP}>\mathrm{CD}+\mathrm{CP}>\mathrm{C}$ $\mathrm{D}+\mathrm{PD}>\mathrm{PD}+\mathrm{BS}>\mathrm{BS}+\mathrm{MS}>\mathrm{PD}+\mathrm{GS}>\mathrm{BS}+\mathrm{CP}$

Thus, the bioremediation of WBLCO contaminated soil can be achieved by treating with crop and animal-derived wastes (PD, CD, 
Citation: Agarry SE, Aremu MO, Aworanti OA (2013) Kinetic Modelling and Half-Life Study on Enhanced Soil Bioremediation of Bonny Light Crude Oi Amended with Crop and Animal-Derived Organic Wastes. J Pet Environ Biotechnol 4: 137. doi:10.4172/2157-7463.1000137

CP, GS, MS and BS) used singly or in combination. The bioremediation process used in this study was simple, inexpensive, efficient and environmentally compatible because by-product of animal and crops regarded as wastes and of no economic value was used to increase crude oil removal. The efficiency of the system depended on the organic nutrients as well as its source, $\mathrm{PD}, \mathrm{CD}, \mathrm{BS}$, and $\mathrm{CP}$ being the most convenient and easily attainable. The bioremediation technique proposed here for soils contaminated with crude oil and other lighter oil distillates could be suitable in field, because of its low costs and its low environmental risk associated with volatile hydrocarbon losses.

\section{References}

1. Bejarano AC, Michel J (2010) Large-scale risk assessment of polycyclic aromatic hydrocarbons in shoreline sediments from Saudi Arabia: environmental legacy after twelve years of the Gulf war oil spill. Environ Pollut 158: 1561-1569.

2. Leahy JG, Colwell RR (1990) Microbial degradation of hydrocarbons in the environment. Microbiol Rev 54: 305-315

3. Kulakow PA, Erickson L (2000) A nationwide field test of petroleum contaminated soils. Proceedings of the 2000 Conference on Hazardous Waste Research, Colorado, USA.

4. Okoh Al (2006) Biodegradation alternative in the cleanup of petroleum hydrocarbon pollutants. Biotechnol Mol Biol Rev 1: 38-50.

5. Ikhajiagbe B, Anoliefo GO (2011) Natural attenuation of a 14-month-old waste engine oil polluted soil. J Soil Sci Environ Manage 2: 184-192.

6. Less ZM, Senior E (1995) Bioremediation. A Practical Solution to Land Pollution. Clean Technology and the Environment. Chapman and Hall, New York, USA.

7. Vidali M (2001) Bioremediation. An overview. Pure Appl Chem 73: 1163-1172.

8. Zhang H, Dang Z, Zheng LC, Yi XY (2009) Remediation of soil co-contaminated with pyrene and cadmium by growing maize (Zea mays L.). Int J Environ Sci Tech 6: 249-258

9. Yerushalmi L, Rocheleau S, Cimpoia R, Sarrazin M, Sunahara G, et al. (2003) Enhanced biodegradation of petroleum hydrocarbons in contaminated soil. Bioremediat J 7: 37-51

10. Abdulsalam S, Bugaje IM, Adefila SS, Ibrahim S (2011) Comparison of biostimulation and bioaugmentation for remediation of soil contaminated with spent motor oil. Int J Environ Sci Technol 8: 187-194

11. Adams RH, Guzmán-Osario FJ (2008) Evaluation of land farming and chemicobiological stabilization for treatment of heavily contaminated sediments in a tropical environment. Int J Environ Sci Tech 5: 169-178.

12. Fulekar MH (2005) Bioremediation techniques for environment. Indian J Environ Protect 25: 358-364.

13. Sarkar D, Ferguson M, Datta R, Birnbaum S (2005) Bioremediation of petroleum hydrocarbons in contaminated soils: comparison of biosolids addition, carbon supplementation, and monitored natural attenuation. Environ Pollut 136: $187-$ 195

14. Chien HY, Kao CM, Jou CJ, Yang PY, Huang CC (2008) Application of enhanced bioremediation to clean up diesel-oil contaminated soils: Laboratory microcosm study. J Biotechnol 136: S682.

15. Chorom M, Sharif HS, Mutamedi H (2010) Bioremediation of a crude oil-polluted soil by application of fertilizers. Iran J Environ Health Sci Eng 7: 319-326.

16. Jobson A, McLaughlin M, Cook FD, Westlake DW (1974) Effect of amendments on the microbial utilization of oil applied to soil. Appl Microbiol 27: 166-171.

17. Huang L, Ma T, Li D, Liang FL, Liu RL, et al. (2008) Optimization of nutrient component for diesel oil degradation by Rhodococcus erythropolis. Mar Pollut Bull 56: 1714-1718.

18. Joo HS, Ndegwa PM, Shoda M, Phae CG (2008) Bioremediation of oilcontaminated soil using Candida catenulata and food waste. Environ Pollut 156: 891-896.

19. Greenwood PF, Wibrow S, George SJ, Tibbett M (2008) Sequential hydrocarbon biodegradation in a soil from arid coastal Australia, treated with oil under laboratory controlled conditions. Org Geochem 39: 1336-1346.

20. Molina-Barahonaa L, Rodríguez-Vázquezb R, Hernández-Velascob M, Vega-
Jarquínb C, Zapata-Pérezc O, et al. (2004) Diesel removal from contaminated soils by biostimulation and supplementation with crop residues. Appl Soil Eco 27: $165-175$.

21. Roncević S, Dalmacija B, Ivancev-Tumbas I, Tricković J, Petrović O, et al. (2005) Kinetics of degradation of hydrocarbons in the contaminated soil layer Arch Environ Contam Toxicol 49:27-36.

22. Maletić S, Dalmacija B, Rončević S, Agbaba J, Petrović O (2009) Degradation kinetics of an aged hydrocarbon-contaminated soil. Water Air Soil Poll 202 149-159.

23. Zahed MA, Aziz HA, Isa MH, Mohajeri L, Mohajeri S, et al. (2011) Kinetic modeling and half life study on bioremediation of crude oil dispersed by Corexit 9500. J Hazard Mater 185: 1027-1031.

24. Kim J, Lee WB (2009) The development of a prediction model for the kinetic constant of chlorinated aliphatic hydrocarbons. Environ Model Assess 14: 93 100

25. Elektorowicz M (1994) Bioremediation of petroleum-contaminated clayey soi with pretreatment. Environ Technol 15: 373-380.

26. Piehler MF, Swistak JG, Pinckney JL, Paerl HW (1999) Stimulation of Diese Fuel Biodegradation by Indigenous Nitrogen Fixing Bacterial Consortia. Microb Ecol 38: 69-78.

27. Rhykerd RL, Crews B, McInnes KJ, Weaver RW (1999) Impact of bulking agents, forced aeration, and tillage on remediation of oil-contaminated soil. Bioresource Technol 67: 279-285.

28. Hollender J, Althoff K, Mundt M, Dott W (2003) Assessing the microbial activity of soil samples, its nutrient limitation and toxic effects of contaminants using a simple respiration test. Chemosphere 53: 269-275.

29. Semple KT, Dew NM, Doick KJ, Rhodes AH (2006) Can microbial mineralization be used to estimate microbial availability of organic contaminants in soil? Environ Pollut 140: 164-172.

30. Walworth J, Pond A, Snape I, Rayner J, Ferguson S, et al. (2007) Nitrogen requirements for maximizing petroleum bioremediation in a sub-Antarctic soil. Cold Reg Sci Technol 48: 84-91.

31. Mills SA, Frankenberger WT Jr (1994) Evaluation of phosphorus sources promoting bioremediation of diesel fuel in soil. Bull Environ Contam Toxicol 53: $280-284$

32. Riffaldi R, Levi-Minzi R, Cardelli R, Palumbo S, Saviozzi A (2006) Soil biologica activities in monitoring the bioremediation of diesel oil-contaminated soil. Water Air Soil Pollut 170: 3-15.

33. Margesin R, Hämmerle M, Tscherko D (2007) Microbial activity and community composition during bioremediation of diesel-oil-contaminated soil: effects of hydrocarbon concentration, fertilizers, and incubation time. Microb Ecol 53 : 259-269.

34. Seklemova E, Pavlova A, Kovacheva K (2001) Biostimulation-based bioremediation of diesel fuel: field demonstration. Biodegradation 12: 311-316.

35. Atlas RM, Bartha R (1998) Microbial Ecology: Fundamentals and Applications Benjamin/Cummings Publishing, Menlo Park, CA, USA.

36. Abioye PO, Abdul AA, Agamuthu P (2009) Enhanced biodegradation of used engine oil in soil amended with organic wastes. Water Air Soil Pollut 209: 173 179.

37. Pala DM, de Carvalho DD, Pinto JC, Sant'Anna Jr. GL (2006) A suitable mode to describe bioremediation of a petroleum-contaminated soil. Int Biodeterior Biodegradation 58: 254-260.

38. Akinde SB, Obire O (2008) Aerobic heterotrophic bacteria and petroleumutilizing bacteria from cow dung and poultry manure. World $\mathrm{J}$ Microbiol Biotechnol 24: 1999-2002.

39. Yakubu MB (2007) Biodegradation of Lagoma crude oil using pig dung. African Journal of Biotechnology 6: 2821-2825.

40. Agarry SE, Owabor CN, Yusuf RO (2010) Bioremediation of Soil Artificially Contaminated with Petroleum Hydrocarbon Oil Mixtures: Evaluation of the Use of Animal Manure and Chemical Fertilizer. Bioremediation 14: 189-195.

41. Okieimen CO, Okieimen FE (2005) Bioremediation of crude oil-polluted soil-effect of poultry droppings and natural rubber processing sludge application on biodegradation of petroleum hydrocarbons. Environ Sci 12: 1-8.

42. http://cornandsoybeandigest.com/manure-makes-sense 
Citation: Agarry SE, Aremu MO, Aworanti OA (2013) Kinetic Modelling and Half-Life Study on Enhanced Soil Bioremediation of Bonny Light Crude Oil Amended with Crop and Animal-Derived Organic Wastes. J Pet Environ Biotechnol 4: 137. doi:10.4172/2157-7463.1000137

Page 11 of 11

43. Nyankanga RO, Onwonga RN, Wekesa FS, Nakimbugwe D, Masinde D, et al. (2012) Effect of Inorganic and Organic Fertilizers on the Performance and Profitability of Grain Amaranth (Amaranthus caudatus L.) in Western Kenya. J Agric Sci 4: 223-232.

44. Alexandratos N (2003) Prospects for Aggregate Agriculture and major Commodity Groups. World Agriculture: Towards 2015/2030, UNFAO, Earthscan Publications, London, UK.

45. OECD (2000) Environmental indicators for agriculture: methods and results. OECD, Paris, France.

46. Bruinsma J (2003) Crop Production and Natural Resource Use. World Agriculture: Towards 2015/2030, UNFAO, Earthscan Publications, London, UK.

47. McLean EO (1982) Soil pH and lime requirement. Methods in Soil Analysis: Chemical and Microbiological Properties. (Part II), American Society of Agronomy, Madison, WI, USA.

48. Nelson DW, Sommers LE (1982) Determination of organic carbon. Method of Soil Analysis. American Society of Agronomy, Madison, WI, USA.

49. Bremner JM, Mulvaney CS (1982) Total nitrogen determination. Method of Soil Analysis. (Vol.2), American Society of Agronomy, Madison, WI, USA.

50. Olsen SR, Sommers LE (1982) Determination of available phosphorus. Method of Soil Analysis. American Society of Agronomy, Madison, WI, USA

51. Amanchukwu SC, Obafemi A, Okpokwasili GC (1989) Hydrocarbon degradation and utilization by a palm-wine yeast isolate. FEMS Microbiol Lett 57: 151-154.

52. Osuji LC, Egbuson EJ, Ojinnaka CM (2005) Chemical reclamation of crude-oilinundated soils from Niger Delta, Nigeria. J Chem Ecol 21: 1-10.

53. Adesodun JK, Mbagwu JS (2008) Biodegradation of waste-lubricating petroleum oil in a tropical alfisol as mediated by animal droppings. Bioresour Technol 99: 5659-5665.

54. Alef K (1995) Estimation of microbial activities. Methods in Applied Soil Microbiology and Biochemistry. Academic Press, New York, USA.

55. Aronson D, Boethling R, Howard P, Stiteler W (2006) Estimating biodegradation half-lives for use in chemical screening. Chemosphere 63: 1953-1960.

56. Sinkkonen S, Paasivirta J (2000) Degradation half-life times of PCDDs, PCDFs and PCBs for environmental fate modeling. Chemosphere 40: 943-949.
57. Dimitrov S, Pavlov T, Nedelcheva D, Reuschenbach P, Silvani M, et al. (2007) A kinetic model for predicting biodegradation. SAR QSAR Environ Res 18: 443457.

58. Matthies M, Witt J, Klasmeier J (2008) Determination of soil biodegradation half-lives from simulation testing under aerobic laboratory conditions: a kinetic model approach. Environ Pollut 156: 99-105

59. Yeung PY, Johnson RL, Xu JG (1997) Biodegradation of petroleum hydrocarbons in soil as affected by heating and forced aeration. $J$ Environ Quality 26: 1511-1576.

60. Liu W, Luo Y, Teng Y, Li Z, Ma LQ (2010) Bioremediation of oily sludgecontaminated soil by stimulating indigenous microbes. Environ Geochem Health 32: 23-29.

61. Akpoveta OV, Egharevba F, Medjor OW, Osaro KI, Enyemike ED (2011) Microbial degradation and its kinetics on crude oil polluted soil. Res $\mathrm{J}$ Chem Sci 1: 8-14.

62. Agbor RB, Ekpo IA, Osuagwu AN, Udofia UU, Okpako EC, et al. (2012) Biostimulation of microbial degradation of crude oil polluted soil using cocoa pod husk and plantain peels. J Microbiol Biotechnol Res 2: 464-469.

63. Nduka JK, Umeh LN, Okerulu IO, Umedum LN, Okoye HN (2012) Utilization of Different Microbes in Bioremediation of Hydrocarbon Contaminated Soils Stimulated With Inorganic and Organic Fertilizers. J Pet Environ Biotechno 3:116.

64. Zhou E, Crawford RL (1995) Effects of oxygen, nitrogen, and temperature on gasoline biodegradation in soil. Biodegradation 6: 127-140.

65. Teng Y, Luo Y, Ping L, Zou D, Li Z, et al. (2010) Effects of soil amendment with different carbon sources and other factors on the bioremediation of an aged $\mathrm{PAH}-$ contaminated soil. Biodegradation 21: 167-178.

66. Cookson WR, Beare MH, Wilson PE (1998) Effects of prior crop residue management on microbial properties and crop residue decomposition. App Soil Ecol 7: 179-188.

67. Jørgensen KS, Puustinen J, Suortti AM (2000) Bioremediation of petroleum hydrocarbon-contaminated soil by composting in biopiles. Environ Pollut 107 245-254. 